\title{
Governo representativo e crise do direito democrático: A confusão entre "democráti- co" e "eleitoral"
}

\author{
Representative government and crises of \\ democratic law: The confusion between "demo- \\ cratic" and "electoral"
}

\author{
Adriana Campos Silva ${ }^{1}$ \\ Ricardo Manoel de Oliveira Moraes ${ }^{2}$
}

Resumo: O objetivo deste texto é analisar, criticamente, a confusão que se estabeleceu na modernidade entre democracia e governo representativo, o que levou a um imaginário de que o processo eleitoral de escolha dos representantes é sinônimo de democratização dos processos decisórios (dentre os quais, o processo

1 Doutora em Direito pela Universidade Federal de Minas Gerais (2002) e Mestre em Direito pela Universidade Federal de Minas Gerais (1990). Professora Decana da Área de Direito Constitucional. Professora da PósGraduação (Direito Político/Direito Eleitoral no Mestrado e Doutorado) e da Graduação (Direito Eleitoral) da Universidade Federal de Minas Gerais.

2 Doutor em Direito Político pela Universidade Federal de Minas Gerais (FDUFMG). Doutorando em Ciência Política pela Universidade de São Paulo (USP). Mestre em Filosofia Política pela Universidade Federal de Minas Gerais (FAFICH-UFMG). Professor de Filosofia do Direito e de Teoria da Constituição na Faculdade de Ensinos Administrativos (FEAD/MG). 
de elaboração do Direito). Na análise, os principais referenciais teóricos são The principles of representative government, de Manin, e Democracia e seus críticos, de Dahl. Conforme será explicitado, na modernidade, emergem uma série de movimentos visando a ampliação da participação nos processos decisórios, levando à emergência do governo representativo. Tenta-se, com isso, proporcionar participação política nas decisões. Todavia, o governo representativo se funda na crença de que o processo eleitoral seria capaz de dar conta dessas reivindicações, criando uma confusão entre democracia e eleição, o que leva a um processo constante de crises jurídico-políticas.

Palavras-chave: governo representativo; eleição; democracia; participação.

Abstract: The objective of this text is to critically analyze the confusion that has arisen in modernity between democracy and representative government, which has led to an imaginary that electoral process of choosing the representatives is synonymous with democratization of the decision-making processes (among which is the process of drafting the law). In this analysis, the main theoretical references are The principles of representative government, of Manin, and Democracy and its critics, of Dahl. As will be explained, in modernity, several movements emerge, in order to expand participation in decision-making processes, which leads to the emergence of representative government. It tries to provide political participation. However, representative government is based on the belief that the electoral process would be able to account for these claims, creating a confusion between democracy and election, leading to a constant process of legal-political crises. 
Keywords: representative government; election; democracy; participation.

\section{Introdução}

Segundo Marramao, "a crise da democracia não é uma simples crise de representação, mas, sim, uma crise que penetra completamente a forma democrática tal como a herdamos dos dois últimos séculos da modernidade" 3 . Embora iniciar um artigo acadêmico com uma citação não seja recomendável em termos metodológicos, a frase do autor italiano é uma excepcional síntese de um fenômeno (a crise política) que passou a marcar a política contemporânea e que será alvo de reflexão deste texto. É imprescindível, primeiramente, esclarecer que quando se fala em "crise do Direito Democrático", o elemento que precede em termos lógicos ao "Direito" e, por conseguinte, ao "Democrático" é a política institucional. O poder político, nesse sentido, pode se instituir de modo democrático ou não, sendo a participação popular o parâmetro. Assim, havendo um conjunto de instituições participativas, capazes de se renovar e se manter abertas às novas potencialidades do real (novos direitos, sujeitos e formas de participação), pode-se dizer que tal regime é democrático. Uma vez que os governos representativos atuais parecem ser cada vez menos capazes de incluir, assegurar direitos àqueles que são vulneráveis, elaborar leis aptas a respeitar a soberania popular, parece haver, de fato, "uma crise [que] penetra totalmente a forma democrática tal como a herdamos".

Tendo em vista a complexidade do fenômeno crise que se manifesta, o objetivo deste artigo é, a partir da constatação

3 MARRAMAO, 2017, s.p. 
de que há uma confusão entre democracia e governo representativo, analisar algumas situações de crises da democracia representativa e eventos recentes ligados a isso. Quando se fala em "Direito", este artigo não possui o escopo de defini-lo, razão pela qual o que será compreendido por esse termo são as instituições jurídicas e judiciárias (bem como as formas de acesso a elas), o processo legislativo e os seus frutos (as leis), as formas de interpretação das leis e da Constituição da República (o principal documento jurídico-político). Nesse sentido, ao examinar a crise do Direito Democrático, o que se intenta apontar é o fato de que as instituições jurídicas, embora existam e funcionem no governo representativo, $\mathrm{o}$ fazem de modo, muitas vezes, não democrático.

Assim, primeiramente, será analisado o processo que levou à emergência do governo representativo na modernidade. Examina-se as principais teorias adotadas, práticas políticas agregadas e problemas que um governo representativo veio resolver. O governo representativo emergiu como uma forma de viabilizar uma polis heterogênea e de grande escala, intentando conciliar a organização complexa e conflitante do Estado Nacional com uma participação política ampla. Por outro lado - e é este o segundo momento do texto -, a representação, assim como a própria noção de governo representativo, não necessariamente democratiza o processo de tomada de decisões. Conforme será desenvolvido, alguns dos principais nomes ligados à teoria e à práxis do governo representativo não só apontaram para um potencial "efeito aristocrático" ao qual esse modelo está sujeito, como defenderam tal efeito como uma virtude.

O "efeito aristocrático" se coloca como uma decorrência do fato de as eleições periódicas serem um dos fundamentos do governo representativo. Ora, na medida em que os eleitores tendem a escolher representantes notáveis (por seu 
saber, habilidade retórica, aparência, riqueza), disso decorre que serão eleitos aqueles que tenham tempo e condições socioeconômicas para adquirirem tal notoriedade ou sejam por estes apoiados ou financiados. Além disso, há a possibilidade de que existam indivíduos que, por seus recursos privados, tenham maior potencial de influenciar os eleitos e as eleições. Logo, eleição e democracia - aqui compreendida também como o modo pelo qual se proporciona a todos, indistintamente, a participação ou a possibilidade de participação política - não são necessariamente sinônimos.

Com isso, crises políticas de participação se colocam como um horizonte político que, se não é constante, é ao menos recorrente. E, tendo em vista que o Direito é uma categoria atrelada aos processos políticos, é inevitável que ele acompanhe tais crises. Se, no Brasil por exemplo, os principais intérpretes da Constituição da República e a cúpula do sistema judiciário são escolhidos pelos representantes; o processo legislativo e a filtragem daquilo que será regido por leis são decididos pelos representantes; e o principal documento jurídico-político pode ser alterado pela classe política eleita: é forçoso inferir que uma crise de representação é, inevitavelmente, uma crise do Direito.

Vale ressaltar que, embora se negue uma crise das instituições políticas como um todo (e, por conseguinte, das instituições jurídico-representativas, que se constituem a reboco da representação) sob o argumento de que, apesar de uma certa crise de representação, as instituições estão funcionando, perde-se de vista que a política e o Direito estão relacionados à representação. E, mais ainda, se o governo representativo se torna um governo não democrático, o mesmo ocorrerá com tudo aquilo que acompanha a representação. Se alguns negam uma crise da democracia, sob o argumento de que as instituições representativas funcionam (pois eleições 
estão sendo feitas, o judiciário mantém sua independência), tal argumento parte do errôneo pressuposto de que o Direito é uma esfera independente da representação.

\section{A emergência do governo representativo moderno}

A noção de governo representativo emerge em um momento histórico que Dahl entende como a segunda grande transformação da democracia no Ocidente. Para ele, a teoria e a realidade da democracia passaram por duas grandes mudanças, uma na antiguidade e outra na modernidade. Evidentemente, isso não significa que, no intervalo, não ocorreram mudanças significativas na noção e práxis democráticas, nem que as duas transformações se consolidaram de uma só vez em seus contextos ou que elas possuem um marco temporal rígido; apenas que, em cada um desses momentos, se constituiu uma transformação crucial da noção de democracia. A primeira transformação ocorreu em meados do século V a.C., quando surgiu a pólis em Atenas ${ }^{4}$ A segunda transformação da democracia (momento em que o governo representativo emerge) é marcada pela consolidação de três elementos: as teorias do republicanismo; a noção de soberania popular; a expansão da cidadania a um corpo populacional mais abrangente ${ }^{5}$. Esses elementos, ao se materializarem, criam um campo sociopolítico para o governo representativo. É nesse momento que surge a noção de que uma comunidade política pode se constituir num corpo social amplo, heterogêneo e plural (diferentemente do que concebiam os gregos). Os ideais democrático-representativos

\footnotetext{
$4 \quad$ DAHL, 2012, p.17.

5 DAHL, 2012, p.35
} 
modernos, embora influenciados pelos antigos, foram moldados pela tradição republicana, pela crença na igualdade política e pela noção de soberania, levando ao advento da representação.

Quanto ao republicanismo, ainda que não se trate de um corpus teórico sistemático, pode-se identificar alguns pontos que o definem. Para os republicanos, o homem é, por essência, um animal político e necessita viver em comunidade para se realizar, sendo o bom cidadão também virtuoso. Além disso, parte desses teóricos sustenta que não se pode excluir segmentos sociopolíticos da participação no governo e, embora atribua grande peso às virtudes, dedica maior atenção à sua fragilidade, ao risco de os atores políticos se corromperem, razão pela qual a virtude estaria no equilíbrio de um governo misto (monárquico, aristocrático e popular ao mesmo tempo). Nesse sentido, a virtude seria uma potencialidade, assim como a corrupção.

O republicanismo assume que o corpo político não é homogêneo, mas é dividido entre um elemento aristocrático e um elemento popular, cada qual com interesses conflitantes em relação ao outro. Pode-se dizer que a boa ordenação deveria equilibrar essa heterogeneidade antagônica, razão pela qual “o modelo constitucional mais óbvio, sem dúvida, era a República Romana, com seu sistema de cônsules, Senado e tribunas populares" ${ }^{\prime \prime}$. Cattoni sintetiza que

[...] o republicanismo concebe a política para além dessa função de mediação social, pois ela é, em primeiro lugar, constitutiva dos processos societários em geral: é a forma em que se reflete a vida ética real, o meio através do qual os indivíduos solidariamente se tornam conscientes de que dependem uns dos outros e, agindo como cidadãos, modelam e desenvolvem suas relações de reconhecimento recíproco, transformando-se numa associação de

$6 \quad$ DAHL, 2012, p.37. 
coassociados livres e iguais perante o Direito ${ }^{7}$.

O republicanismo se divide entre os aristocráticos e os populares. "Na visão republicana aristocrática, embora o povo (os muitos) deva ter um papel importante no governo, o fato de que ele inspira mais medo que confiança exige essa participação limitada" 8 . A república aristocrática pressupõe uma estrutura que restrinja os impulsos populares, e mesmo que o povo deva ter alguma participação, ainda deve ser refreado, por ser irracional. A participação popular se limitaria à chancela do que os virtuosos realizassem. Por outro lado, o segmento democrático defende que o elemento a ser temido é a elite. Caso os grandi sejam deixados sem freios, corromperão o bem comum para impor seus interesses. $\mathrm{O}$ bom governo depende de instituições aptas a cultivar boas qualidades no povo, sendo a principal tarefa constitucional criar um regime apto a superar a tendência despótica da elite de corromper as instituições. Os aristocráticos defendiam que o povo, embora tivesse uma concepção de bem comum, o entendia equivocadamente, razão pela qual os grandi deveriam governar. Por outro lado, os democráticos entendiam que os interesses antagônicos dos nobres e do povo deveriam ser conciliados, mas que o povo deveria ser protagonista por possuir um juízo político privilegiado.

As principais marcas do republicanismo são a tese de que a pólis é heterogênea e que os segmentos políticos possuem interesses antagônicos que devem ser considerados igualmente. Além dos ideais republicanos, as teorias da soberania foram fundamentais na segunda transformação da democracia. No período conhecido como Baixa Idade Média, a noção de soberania emerge e, alguns séculos mais tarde,

\footnotetext{
7 CATTONI, 2007, p.6.

8 DAHL, 2012, p.38.
} 
irá viabilizar o campo no qual o Estado se colocará como o centro da política ${ }^{9}$. Pode-se dizer que a unificação teórica de uma série de práticas jurídicas e políticas difusas em torno de uma figura (o soberano e, posteriormente, o Estado, onde o povo soberano se faz representar) só foi possível pelo advento das teorias da soberania. Essas teorias nasceram por "encomenda" régia, tendo sido a sua primeira função a de legitimar as arbitrariedades e os privilégios reais.

Se a noção de soberania era desconhecida na polis grega, com a efervescência de conflitos relacionados a territórios, povos, legitimidade e autoridade, o princípio da soberania se torna um imperativo, segundo o qual deve haver uma potência política para além da sociedade civil que seja, perante ela, o mais alto poder. Essa potência interna, coexistindo no âmbito externo com outros soberanos e respeitando a territorialidade (uma vez que a autoridade máxima soberana é exercida dentro do território), se traduz em um poder absoluto no âmbito interno e como um poder entre iguais no âmbito externo. Assim, as teorias da soberania legitimam o poder supremo a ser exercido sob uma coletividade em um determinado território por uma determinada autoridade, seja ela régia ou constituída popularmente ${ }^{10}$.

Por que a necessidade de firmar a soberania como poder incontrastável? Por motivos sobretudo de ordem histórica. O Estado moderno, cujo nascimento testemunharam teoristas políticos da envergadura de Bodin, precisava de impor-se. Sua formação vinha precedida dos antagonismos da Idade Média entre o poder espiritual e o poder temporal, entre o imperador germânico-romano e os novos reis que surgiam da decomposição dos feudos. Sobre essa decomposição se levantava nova ordem de agregações políticas mais prestigiosas. De modo que um poder novo se firmou

9 FOUCAULT, 1999, p.27-40.

10 BONAVIDES, 1997, p.124. 
no Estado moderno e este poder foi o poder dos monarcas independentes; poder absoluto, que precisava de justificação teórica ${ }^{11}$.

Assim, “[...] um poder novo se firmou no Estado moderno e este poder foi o poder dos monarcas independentes; poder absoluto, que precisava de justificação teórica"12. Segundo Bonavides, "o princípio da soberania começa historicamente por exprimir a superioridade de um poder, desembaraçado de quaisquer laços de sujeição"13. Para ele, “a soberania é una e indivisível, não se delega a soberania, a soberania é irrevogável, a soberania é perpétua, a soberania é um poder supremo [...]"14.

Para Foucault, as teorias da soberania são marcadas por um profundo paradoxo. Quando a figura soberana se torna pouco eficaz, passando a ser questionada pela obrigatoriedade de todos seguirem a lei, o rei passa a ter o dever de agir dentro da legalidade, sob pena de perder a legitimidade, $o$ que marca o início da modernidade. Isso porque, se, no contexto medieval, elas tiveram a função de legitimar a figura do soberano absoluto, na modernidade, elas passaram a mascarar as arbitrariedades estatais ou de grupos que se apropriam do Estado valendo-se de uma chancela institucional como o sufrágio ou a representação. $\mathrm{O}$ discurso soberano moderno ajudou a mascarar a perversidade de uma série de práticas estatais, econômicas, judiciárias e eleitorais, naturalizando-as no governo representativo. A soberania se deslocou para o sujeito coletivo povo e esse deslocamento se materializa em uma série de símbolos, como a figura do "Legislador Racional", a instituição do Parlamento e o corpo institucional das

11 BONAVIDES, 1997, p.126.

12 FOUCAULT, 1999, p.30.

13 BONAVIDES, 1997, p.124-125.

14 BONAVIDES, 1997, p.126. 
três funções do Estado. Essas figuras passam a personificar a soberania, como se representassem o povo.

Ao se colocar o povo como o detentor da soberania e ao considerá-lo como uma totalidade política una (pois o povo é soberano, e a soberania é una) e, ao mesmo tempo, heterogênea (pois o povo é plural) em um território, surgem alguns problemas que não se resolvem pela tradição republicana moderna:

Em primeiro lugar, como os republicanos democráticos do século XVIII começaram a perceber, o conceito de interesse ou interesses no republicanismo ortodoxo era simples demais. Ainda que algumas sociedades tivessem sido estratificadas nos interesses do indivíduo, dos poucos e dos muitos, não era mais isso o que acontecia. Como, portanto, poderiam os interesses de sistemas mais complexos ser compreendidos e, se necessário, representados ou "equilibrados"? Em segundo lugar, como poderia uma república ser planejada de modo a lidar com os conflitos que uma diversidade de interesses parecia tornar inevitáveis? Afinal, apesar de toda a conversa grandiloquente sobre a virtude cívica e o equilíbrio de interesses, na prática, o conflito era um aspecto pronunciado e, pode-se dizer, normal, da vida política em repúblicas anteriores. Deveriam os partidos políticos, que surgiram de forma rudimentar e bastante duradoura na Inglaterra do século XVIII, ser banidos de alguma forma da vida pública a fim de garantir a tranquilidade pública? Se esse fosse o caso, como isso poderia ser feito sem destruir os aspectos essenciais do próprio governo republicano? Em terceiro lugar, se o governo republicano depende da virtude de seus cidadãos, e se a virtude consiste na dedicação ao bem público (e não aos próprios interesses do indivíduo, ou aos interesses de alguma parte do "público"), será que uma república é realmente possível, particularmente em sociedades grandes e heterogêneas como as da Grã-Bretanha, da França e da América? A resposta republicana ortodoxa era simples: as repúblicas poderiam existir apenas nos pequenos Estados [...]. Mas se fosse assim, a tradição republicana não teria importância alguma para a grande tarefa com a qual os republicanos democráticos estavam firmemente comprometidos: democratizar os grandes Estados nacionais do mundo moderno. Em quarto lugar, portanto, poderiam a teoria 
republicana e as ideias democráticas, de modo geral, ser aplicadas à escala do Estado nacional ${ }^{15}$

O governo representativo emerge como a tentativa de resposta a esses problemas. O governo representativo tenta conciliar uma organização social complexa, conflitante e heterogênea com uma participação política de um grande número de pessoas. E, para que isso seja possível, a organização estatal deve ser soberana e capaz de congregar, ao menos formalmente, a pluralidade social. Caso contrário, ou (1) a sociedade poderia se consumir em conflitos internos (oriundos da heterogeneidade da população e dos clamores pela ampliação da participação política, que são progressivamente atendidos) sem espaço de resolução institucional, ou (2) o Estado poderia ser colocado a serviço de um grupo em detrimento de outro. A tentativa de responder a isso veio na segunda grande transformação da democracia, com a "soberania popular". Se o povo é soberano, com o passar dos séculos, chega-se à máxima política de que não pode haver segmentos excluídos da participação, a não ser que tenha havido, antes da exclusão, uma decisão democrática (como é o caso da exclusão das crianças do demos).

Logo, pode-se dizer que a noção de democracia moderna se firma a partir do governo representativo, que, por sua vez, congrega em seu corpo institucional marcas dos três elementos da segunda transformação da democracia. Assim, devido ao fato de que as comunidades políticas não eram mais pequenas e homogêneas, somando-se a isso crescentes demandas por ampliação da cidadania, surgiu a noção de governo representativo. Mas, se o Estado deve se estruturar como um governo representativo do povo soberano em seu exercício de poder, quais deveriam ser os parâmetros de uma 
organização política que materializasse essa necessidade de modo democrático e inclusivo? Manin ${ }^{16}$ apresenta os princípios do governo representativo: 1) representantes eleitos pelos governados; 2) independência parcial dos representantes diante das preferências dos eleitores; 3) manifestação independente de controle do governo da opinião pública sobre assuntos políticos; 4) decisões políticas tomadas após o debate político.

Quanto ao primeiro princípio (representantes eleitos pelo povo), embora a natureza exata da representação seja algo complexo, tem-se como premissa o fato de que só há representação se os governantes forem eleitos periodicamente. Isso porque, no sistema de governo representativo, há uma clivagem entre os eleitores e os eleitos, na medida em que estes irão exercer autoridade sobre aqueles. Caso o corpo de representantes não seja submetido a um processo de controle político periódico, não haverá representação, mas a simples autoridade de uns sobre outros. O processo político da eleição tem o objetivo de reduzir essa diferença hierárquica entre povo e governo. Além disso, a eleição, enquanto método de escolha daqueles que irão governar, opera de modo a conferir legitimidade aos atos dos governantes.

Vale frisar que o sistema eleitoral não requer que os governantes sejam semelhantes aos governados, pois os representantes podem ser ilustres, ricos, social e culturalmente distintos dos representados. Um governo eleito pode, inclusive, ser um governo de elite, desde que não exerça o poder em função de seus próprios interesses. Logo, o sistema eleitoral cria um paradoxo. Primeiramente, não há, necessariamente, uma identidade entre governantes e governados. Além disso, esse princípio, por si só, cria uma situação na qual o povo

16 MANIN, 1997, p.163-192. 
não governa a si mesmo, podendo apenas, caso uma decisão o desagrade, votar em outro candidato no futuro.

Quanto ao segundo princípio (independência parcial dos representantes em relação às preferências do eleitorado), ainda que os representantes sejam escolhidos por um número amplo de eleitores, eles possuem um certo grau de independência em suas decisões. Segundo Manin, esse princípio pode ser visto a partir de duas práticas políticas que foram rejeitadas pelo sistema representativo e que poderiam retirar a autonomia dos representantes: os mandatos imperativos e a revogabilidade permanente e discricionária dos mandatos dos eleitos. Desde o final do século XVIII, nenhum governo representativo determinou que seus representantes obedecessem a instruções dadas pelos eleitores ou cumprissem à risca seus projetos políticos. Pode-se afirmar que, desde essa época, não existem mandatos imperativos. Evidentemente, existem meios de se pressionar os representantes como petições, manifestações ou ameaças de votar em outros candidatos. Todavia, há uma diferença entre pressão política e mandato imperativo. Também a revogação discricionária e permanente de mandatos não foi adotada e, assim como formas de pressão não se confundem mandatos imperativos, o impeachment ou o voto de desconfiança são distintos de revogação discricionária e permanente do mandato.

Quanto ao princípio da manifestação da opinião pública independentemente do controle do governo, há a noção de que os governados devem formular e expressar livremente suas opiniões acerca dos assuntos políticos e dos governantes. A liberdade de opinião política pressupõe, nos termos de Manin, dois elementos. O primeiro é que, para que os governados possam formular as suas opiniões acerca dos assuntos políticos, eles devem ter acesso às informações políticas, o que pressupõe que os processos de deliberação 
e de decisão governamentais sejam públicos. Caso as decisões e deliberações sejam realizadas em segredo, sem uma ampla e prévia divulgação, os governados não irão dispor de dados sólidos para elaborar suas opiniões e expressá-las. Em segundo lugar, deve haver liberdade de expressão no que diz respeito à opinião política formulada. Embora esse segundo elemento pareça óbvio, em determinados sistemas, as deliberações e as tomadas de decisões se dão sem que as pessoas possam se expressar publicamente acerca delas, embora se saiba que elas ocorrem.

Por fim, há o princípio de que as decisões políticas devem ser tomadas após amplos debates, que, por sua vez, devem ser públicos. É notória a ideia de que o governo representativo foi concebido e justificado como o governo do debate. No governo representativo, há o pressuposto de que a assembleia política (o parlamento, o congresso) desempenha o papel decisivo no sistema político. Isso porque a representação pressupõe que o poder não pode ser confiado a um único indivíduo com a prerrogativa de exercer todas as funções de Estado, bastando, para isso, a vitória eleitoral. Assim, da obrigatoriedade do debate, advém uma máxima do governo representativo: nenhuma medida pode ser tomada ou considerada válida a não ser que tenha obtido o consentimento de uma maioria ao final dos debates.

\section{Governo representativo: democracia/licença versus aristocracia/oligarquia}

A constituição moderna do governo representativo possui arranjos institucionais visando assegurar a responsabilização dos agentes públicos (como eram os tribunos romanos analisados por Maquiavel), como (1) o sistema de recompensa com a eleição e reeleição pelo trabalho bem 
realizado e a sanção por ofícios mal prestados, (2) uma composição institucional marcada pela separação funcional do poder político e (3) a ameaça de, em casos extremos, remoção do agente de seu ofício por processos de impeachment conduzidos pelos legitimados ${ }^{17}$. Soma-se a esse arranjo o processo da eleição como meio de escolha dos representantes. Devido à obrigatoriedade de eleições periódicas, a representação passa a ser pensada como um misto entre voto e deliberação, autorização/delegação formal e influência informal, como uma relação dinâmica entre representantes e representados.

Vale frisar que os princípios do governo representativo moderno pouco se alteraram desde o seu advento. "No século XVIII, os autores começaram a ver o que os Levellers já haviam percebido: que ao unir a ideia democrática de governo do povo à prática não democrática da representação, a democracia podia assumir uma forma e uma dimensão totalmente novas"18. Nesse sentido, diante da necessidade de se democratizarem as vias institucionais representativas, o governo representativo emerge. Contudo, é claro que, inicialmente, sua feição não era propriamente a de um governo democrático, já que a ampliação da participação foi progressiva.

Inicia-se, também na modernidade, um processo político (que acompanha o processo de ampliação da participação) em que o Estado se torna um agente autônomo face aos governados e o centro da política. Weber, ao definir o Estado, conceitua-o como "[...] uma associação compulsória que organiza a dominação"19. O Estado seria o espaço da política, da "[...] participação no poder ou a luta para influir na distribuição de poder, seja entre Estados ou entre grupos

17 MCCORMICK, 2011, p.91.

18 DAHL, 2012, p.43.

19 WEBER, 1982, p.59. 
dentro de um Estado" ${ }^{20}$. É central reter que o Estado, para que se constitua nesses termos (organizador da dominação; detentor da força; espaço da política), deve ser autônomo - pois é composto por agentes políticos e por um corpo burocrático que são independentes da vontade popular - e se projetar para além da sociedade, mas também se manter aberto a ela para não ser autoritário. Além disso, na medida em que o Estado se coloca como uma potência cujo poder será exercido sobre a sociedade, torna-se premente conferir legitimidade representativa à ação estatal, o que passa a ser o horizonte político moderno.

Segundo Dahl, a transformação do paradigma democrático que resultou da união entre a autonomia do governo e a representação teve consequências profundas. "A consequência mais importante, como todos sabiam, foi que o governo popular não precisou mais confinar-se aos Estados menores, mas pôde, então, estender-se quase indefinidamente até incluir um grande número de pessoas" 21 . Esse processo de inclusão política do governo representativo não foi linear, nem se deu em um só lugar ou com pressupostos e finalidades definidos. O que se pode dizer é que o alargamento progressivo da participação teve como causa a crescente reivindicação por setores da sociedade, decorrência da separação entre Estado e sociedade. Como o Estado se torna uma potência autônoma, passando a agir autonomamente e a exercer poder sobre a sociedade, surgem movimentos que buscam participação nesse ente autônomo. Com isso, a emergência do governo representativo é acompanhada de um lento processo em que o povo será incluído no demos, isto é, uma ampliação da cidadania a um número cada vez maior de pessoas. Nesse sentido, entre as tentativas de democra-

\footnotetext{
20 WEBER, 1982, p.56.

21 DAHL, 2012, p.44-45.
} 
tizar o governo, está a ampliação progressiva do demos, que alcança seu apogeu na "democracia de massa".

Com isso, a eleição se torna um requisito indispensável para a legitimidade do agir político protagonizado pelo Estado e para a nomeação dos principais cargos, de modo que o Estado e a sociedade civil não mais puderam ser desconectados (embora, por vezes, ocorram graves afastamentos entre eles). Traçar fronteiras entre Estado e sociedade se tornou uma problemática de constante reajuste e negociação, sendo a representação o espelho dessa tensão, devendo os representantes refletir não só suas ideias, mas a pluralidade do demos. Toda e qualquer reivindicação que os cidadãos tragam à arena política se constitui como um reflexo da luta para a definição das fronteiras entre a sociedade e o Estado ${ }^{22}$.

Todavia, deve-se refletir sobre a natureza política deste modelo, já que o processo político da eleição como forma de escolha dos representantes - e a própria noção de representação - nem sempre foi uma noção ligada a ideais democráticos. Na Antiguidade, as eleições eram compreendidas como uma instituição aristocrática, pois potencializa a tendência elitista de que os cidadãos comuns escolham os proeminentes. Estes, por sua vez, só são capazes de adquirir proeminência se possuírem uma vantagem socioeconômica que lhes proporcione a oportunidade de aprimoramento intelectual e retórico. Ainda, a vantagem socioeconômica viabiliza o acesso a uma aparência distinta e a uma maior capacidade de influenciar a política.

Não obstante, um defensor de um governo popular - como Maquiavel - dificilmente consideraria o governo representativo como democrático ou popular ao avaliar sua tendência de deixar os cidadãos ricos e proeminentes livres para ocupar todas as magistraturas, já que eleições e

22 URBINATI, 2006, p.193. 
institutos meritocráticos são o meio principal de escolha dos agentes públicos. Assim, como os cidadãos ricos possuem vantagens em relação aos demais - pois a riqueza permite que eles cultivem reputação, aparência distinta, habilidades de discursar e ócio para aperfeiçoamento pessoal -, disso decorre que os eleitores, quase sempre, os escolham. Além disso, os recursos financeiros permitem que os ricos financiem candidatos que sirvam seus interesses. Em suma, a eleição continua sendo um método que favorece a elite e impede que os ofícios sejam distribuídos igualmente. Logo, pode-se questionar se o governo representativo é, de fato, democrático ou se esse "efeito aristocrático" é intransponível.

Não bastasse o risco de a representação se constituir como um sistema de elites, alguns idealizadores do modelo representativo irão abraçar esse "efeito aristocrático", sustentando que esse seria um aspecto positivo do governo representativo. O parlamentar britânico Edmund Burke, por exemplo, defendeu abertamente a importância da constituição de uma elite para lidar com os assuntos políticos. Grosso modo, Burke defendia que toda a nação deveria ser representada pelo parlamento e pelos parlamentares. Para ele, as desigualdades eram não apenas incontornáveis, mas naturais, e se elas fazem parte de toda e qualquer sociedade, seria natural e até mesmo inevitável que alguns cidadãos tivessem um patamar mais elevado que os demais.

Outro minimalista é Schumpeter ${ }^{23}$. Para ele, o objetivo do governo representativo é constituir uma elite eleitoral. Embora não empregue o termo "elite", ele afirma que, no governo representativo, não é o povo que deve decidir sobre a vida pública, mas os eleitos. $O$ povo sequer deve governar de forma indireta, apenas selecionar, dentre um número de competidores, aqueles que irão tomar as decisões políticas.

23 SCHUMPETER, 1961, p.321. 
Schumpeter define o governo representativo como um arranjo institucional apto a tomar decisões políticas, onde indivíduos adquirem o poder de decidir por meio de uma concorrência igualitária pelos votos do povo. Democracia representativa significa que o demos deve apenas aceitar ou recusar os que governam. O critério para a tomada dessa decisão é a concorrência entre candidatos pelo voto livre do eleitorado. Logo, os representantes não são encarregados de implementar a vontade popular.

Alguns pressupostos comuns às teorias minimalistas da democracia são: a necessidade de constituir representantes pela via eleitoral que sejam independentes dos eleitores; o povo em geral não é capaz de se governar, devendo sua participação se reduzir, tão só, à escolha de um grupo restrito de cidadãos que tome as decisões; um distanciamento entre representantes e representados, de modo que os representantes não se "contaminem" com a irracionalidade e suscetibilidade popular; e a noção de que os eleitos seriam aptos para decidir de acordo com o bem comum e de modo imparcial por serem dotados de uma excepcional virtuosidade.

Sendo pressuposto dos minimalistas que o povo não é hábil, virtuoso ou sábio o suficiente para se autogovernar, sua participação deve ser mitigada, periódica e eventual (plebiscitos ou referendos). Devido a isso, Dahl aponta que se esse modelo é composto e dirigido por uma elite e se isso é algo positivo, o governo representativo é democrático? A premissa de que o povo não é inapto para governar pode ser considerada democrática? Dahl, no capítulo 4 de Democracia e seus críticos, chama de "guardiania" 24 as teorias que

24 A guardiania parte de dois dogmas: o conhecimento do bem comum e dos meios mais aperfeiçoados para alcançá-lo seria parte de uma ciência composta por verdades objetivas que só podem ser atingidas por indivíduos sábios e superiores; esse conhecimento poderia ser alcançado apenas por uma minoria. Com relação ao conhecimento moral elevado como exigência 
defendem que o governo deve ser confiado a uma minoria de virtuosos. Os teóricos dessa corrente partiriam da premissa de que o povo deve ser excluído da participação política direta por ser inapto à política. Platão $0^{25}$ pode ser considerado como o principal teórico guardianista. Dahl critica a "democracia minimalista" shumpeteriana justamente por não haver como diferenciá-la das doutrinas da guardiania. Não obstante, regimes que excluem a participação efetiva do povo no governo tendem a ser, como Maquiavel demonstra, desequilibrados.

para os governantes, há o pressuposto de que os juízos morais podem ser compreendidos como ciências naturais, ou seja, como lei universal e absoluta. Todavia, tais juízos jamais foram comprovados. Caso a ética fosse uma ciência capaz de alcançar leis morais absolutas, não haveria dilemas morais ou mesmo discussões sobre éticas. O homem deixaria de ser um ser político e passaria a ser um animal guiado por leis absolutas. No que diz respeito à exigência de um conhecimento técnico-instrumental elevado, surgem questões problemáticas. Segundo essa premissa, governar seria um campo do saber como qualquer outro. Logo, assim como o indivíduo mais qualificado para tomar decisões sobre questões técnicas é o especialista, o mesmo se daria com relação aos assuntos políticos. Em outras palavras, a política se resumiria à administração pública. Todavia, esses pressupostos são, no mínimo, radicalmente questionáveis. Além disso, não há qualquer garantia de que tais conhecimentos elevados poderiam ser alcançados apenas por uma minoria (DAHL, 2012, p.100-105).

25 Em síntese, pode-se dizer que Platão critica a democracia por ser uma polis sem unidade, onde qualquer um opina e segue suas próprias decisões. A democracia seria análoga a uma embarcação desgovernada, cujo leme toda a tripulação tenta tomar desordenadamente. A proposta platônica é a de um Estado que seja governado por filósofos que conhecem o Bem e a Justiça e que se dedicam inteiramente ao público, promovendo a eudaimonia de todos, o que só é possível se a ordem racional reinar, o que não é viável numa democracia, pois nem todos são propensos à razão e, por conseguinte, ao conhecimento do Bem. Assim como ele, Guicciardini e Madison defendem que o governo da cidade deve ser deixado a cargo daqueles que são efetivamente preparados para tal função. 


\section{Crises de representação}

Como exposto, no governo representativo são escolhidos representantes por eleição. Todavia, tal sistema pode gerar um "efeito aristocrático", cujo principal desdobramento é a impossibilidade de conciliar participação ampla, autogoverno popular e eleição. $\mathrm{O}$ governo representativo faz com que surja uma espécie de hierarquia entre dois tipos de cidadania: a política, que é aquela cujos cidadãos irão verdadeiramente deliberar e decidir sobre os assuntos políticos, e a cidadania civil, que assegura o direito de escolher os detentores da cidadania política e, eventualmente, opinar em referendos e plebiscitos. Devido a isso, alguns teóricos irão partir da premissa de que esse modelo é de fato "aristocrático", e o que faz com que ele não seja oligárquico são as eleições periódicas e a universalidade do sufrágio. Entretanto, se de fato o governo representativo for de uma minoria sobre os demais, esse modelo não poderia ser classificado como democrático, pois não há como diferenciá-lo de uma "guardiania".

Surge, assim, uma crise no âmago do governo representativo: a tensão entre a busca por participação efetiva e o efeito aristocrático. E, nos momentos em que esta tensão se manifesta e se torna perceptível, é comum tratá-los como contextos de "crise representativa". Essa, por sua vez, tende a se resolver por uma reforma institucional, de modo a reequilibrar o jogo de interesses ao ampliar ou efetivar a participação. Com a reforma, o sistema representativo pode sofrer uma metamorfose (como será descrito a seguir) ou uma reforma pontual. Caso ocorra uma reforma pontual, pode ser que haja, por exemplo, a inclusão de um grupo nas instituições por meio de um sistema de quotas ou uma alteração em regras eleitorais secundárias, o que não irá, de 
fato, reaproximar a sociedade das instituições representativas, ofuscar a referida tensão por um certo período. Ou seja, a partir da tendência elitista ao qual está vinculada a gênese do governo representativo, é possível situar esta organização política num campo onde crises de representação estão sempre no horizonte, sendo esses sintomas de uma crise mais ampla, que decorre da dificuldade de conciliar participação popular plena e representação.

Manin diferencia as três formas que o governo representativo assumiu na modernidade. Embora ele não detalhe o modo como se deu a passagem de um modelo para o outro, pode-se evidenciar a crise de representatividade oriunda do distanciamento entre representantes e representados que precedeu cada metamorfose. A primeira forma do governo representativo foi o parlamentarismo. Nela, as eleições eram o meio pelo qual se conduziam ao governo os proeminentes da confiança dos cidadãos. A confiança decorria do fato de o representante pertencer à mesma comunidade dos eleitores, definindo-se a comunidade em função dos interesses do reino (propriedade fundiária, manufatureira, mercantil) ou em função puramente geográfica. Os representantes não se constituíam pela concorrência, mas pela mobilização de recursos pessoais (riqueza e proeminência). O governo parlamentar é o "reinado dos notáveis".

Aqui, os eleitos eram livres para votar de acordo com seu julgamento pessoal, estando desvinculados de uma vontade política externa ao parlamento. Os parlamentares não eram porta-vozes dos eleitores, mas homens que detinham a confiança deles. A grande independência de cada deputado em relação à vontade dos eleitores se devia ao fato de que o representante era eleito por fatores pessoais. Devido a isso, durante o período em que o governo parlamentarista era o estruturante, surgiram associações e movimentos políti- 
cos extraparlamentares (cartismo, defesa dos direitos dos católicos, reforma parlamentar, repúdio à lei do trigo) que passaram a organizar manifestações, petições e campanhas de imprensa. Com isso, a expressão livre da opinião começou a se chocar com a participação restrita, já que a manifestação da preferência política se dava apenas na eleição. Isso fez com que os movimentos de reivindicação para que o parlamento considerasse a vontade popular crescessem. Assim, devido aos conflitos oriundos do distanciamento entre as deliberações parlamentares e as exigências para que a vontade popular fosse considerada nas deliberações parlamentares, o risco de desordens sociais crescia, não sendo a relação de confiança pessoal suficiente para manter a estabilidade. Desse modo, o parlamentarismo se transformou no modelo que Manin denomina democracia de partido.

As principais marcas da democracia de partido são a ampliação do sufrágio e a diminuição da liberdade do parlamentar frente a disciplina partidária. $\mathrm{O}$ aumento do eleitorado gerado pela ampliação do sufrágio fez com que os deputados não pudessem mais manter laços pessoais com o eleitorado. Assim, os cidadãos passam a não mais votar no candidato em quem eles confiam pessoalmente, mas naqueles que estão vinculados a partidos de sua preferência. Os partidos possuem uma diretriz ideológica que é genericamente conhecida pelos eleitores, sendo possível prever o modo como os representantes agirão. A emergência dos partidos criou certa estabilidade no comportamento eleitoral, pois os eleitores tendiam a votar nos candidatos que representassem os seus interesses de classe. Portanto, embora os parlamentares continuassem livres para votar de acordo com seu julgamento, ficavam presos à disciplina partidária e, tendo em vista que o sufrágio foi estendido e as formas extraeleitorais de influência política se multiplicaram, 
operou-se uma reaproximação entre instituições políticas e "povo".

Os partidos políticos, com suas redes de militantes e estruturas burocráticas, surgiram para mobilizar o eleitorado crescente. Com a crença de que o "cidadão comum" poderia ascender ao poder via partidos de massa, houve a falência do notável e o aparente fim do elitismo parlamentarista. Além disso, o fim do censo e a ampliação do sufrágio fizeram com que o eleitorado ganhasse considerável heterogeneidade étnica, cultural, ideológica, política e econômica. Assim, surgiram os partidos de massa, sendo os partidos socialistas e social-democratas os arquétipos. Para a maioria dos eleitores socialistas, o voto não era só uma escolha, mas uma questão de identidade social. Os eleitores confiavam nos candidatos do partido, pois os reconheciam como membros do seu grupo social. Com a heterogeneização do eleitorado, as divisões sociais ficaram mais claras: havia o conservador, definido por valores tradicionais, e o socialista, definido pela posição social e pela preocupação com novos valores.

De início, predomina a pluralidade como constitutivo da representação. Contudo, os setores sociais que se manifestavam através das eleições estavam em conflito entre si. Assim, se no parlamentarismo a eleição refletia uma realidade social anterior à política (riqueza e proeminência), na democracia de partido os segmentos em conflito passam a ter importância, adotando-se a premissa de que todos devem ter espaço institucional com representantes. E, ainda que se possa pensar que essa modalidade do governo representativo aumenta o risco de confrontos abertos e violentos por se abrir ao antagonismo das classes, ocorre justamente o oposto. É por se abrir às cisões sociais que a democracia de partido se torna viável, pois os interesses opostos aceitam o princípio da conciliação, que se manifesta, por exemplo, na 
estratégia de coalizão. Com a coalizão, o partido vitorioso não será capaz de realizar todos os seus projetos, devendo aceitar interesses que não são os seus. A vitória eleitoral não significa que os interesses representados pelos demais partidos serão ignorados até a eleição seguinte.

Por fim, opera-se outra metamorfose no governo representativo. Se o início da formulação da democracia de partido é marcado por uma ampla representatividade decorrente da ampliação do sufrágio, com o passar do tempo, ocorre outra crise política. Os partidos, ainda que tenham sido instrumentos essenciais para resolver crises de representação, deixaram de ser, de fato, representativos. As coalizões fazem com que seja difícil para o eleitor identificar a causa de um governo ruim, pois os partidos e os atores políticos transferem a responsabilidade uns para os outros. Ainda, alguns atores oriundos de classes operárias, ao alcançarem o poder, passam a levar uma vida burguesa, diferenciando-se da base. No capitalismo, esse sistema proporcionaria a alguns membros do operariado a oportunidade de ascensão social. Com isso, os partidos socialistas acabaram dominados por "elites desproletarizadas".

Além da crise dos partidos e do sistema de coalizão, autores como Kirchheimer ${ }^{26}$ mostram as transformações do sistema partidário que tornaram esse modelo insuficiente. “Usando o termo catch-all-parties ('partido pega-tudo') [ele] procura mostrar como os partidos perderam gradativamente suas identidades. Se 'pegam tudo' não há distinções programáticas e ideológicas precisas que possam estabelecer diferenças entre eles" ${ }^{27}$. Para Kirchheimer, muitos partidos se burocratizaram e deixaram suas posições de classe, tentando

26 KIRCHHEIMER, 2012, s.p.

27 COSTA, 2010, p.276. 


\section{formular propostas difusas visando abarcar "todo o povo" com finalidades "eleitoreiras".}

O potencial de integração do partido de massa catch-all baseia-se na combinação de fatores cuja finalidade resultante visível é a atração do máximo número de eleitores no dia da votação. Para obter tal resultado, o partido catch-all deve ter conseguido entrar em milhões de mentes como se fora um objeto familiar, preenchendo na política um papel análogo àquelas grandes marcas no mercado de artigos de consumo de massa universalmente necessários e altamente estandardizados. Não importa quais sejam as particularidades inerentes ao líder partidário, que, inclusive, garantiram sua ascensão no interior da organização, assim que for selecionado para a liderança, ele deve adaptar rapidamente seu comportamento segundo os requisitos da padronização. Há a necessidade de alguma diferenciação da marca, de modo a tornar o produto plenamente reconhecível, porém, o grau dessa diferenciação jamais deve ser tão elevado a ponto de fazer com que o potencial consumidor tema ser relegado ao limbo. [...] O próprio caráter catch-all do partido torna mais difícil qualquer expectativa de lealdade da militância ou, no melhor dos casos, ela nunca é suficiente para alterar os resultados. $\mathrm{O}$ resultado de um debate televisivo é dúbio ou o debate em si mesmo constitui uma exposição muito fugaz para deixar alguma impressão duradoura até a eleição. Assim, o partido de massa catch-all também é voltado à busca de uma clientela mais permanente. Somente algum grupo de interesse, seja de natureza ideológica ou econômica, ou ainda uma combinação de ambos, é capaz de prover massivas reservas de eleitores prontamente acessíveis. Ele tem uma linha de comunicação mais constante e maior receptividade para suas mensagens do que as tem o partido catch-all, o qual é afastado do contato direto com o público, exceto pelo comparativamente menor número de indivíduos intensamente preocupados com a marca política que um partido tem que oferecer atualmente - ou com suas próprias carreiras seja dentro do partido ou por intermédio dele ${ }^{28}$.

Nesse sentido, pode-se sublinhar o fato de os partidos terem, na segunda metade do século XX, se tornado "máqui-

28 KIRCHHEIMER, 2012, s.p. 
nas eleitorais" pautadas pelo pragmatismo político, levando à "desradicalização" ideológica e à indistinção programática. Assim, as ações de governo da "direita" e da "esquerda", do "partido conservador" e do "partido progressista" ou do "partido socialista" e do "partido liberal" quase não se distinguem, levando a uma crise de identidade entre o demos e os representantes. Dessa forma, de outra "crise de representatividade" emerge o modelo representativo denominado democracia do público.

A democracia de público tem como marca uma nova personalização da escolha eleitoral, decorrente do aprimoramento dos meios de comunicação. Os candidatos passam a poder se comunicar diretamente com o eleitor pelo rádio ou televisão, dispensando a mediação da rede partidária. Os próprios candidatos, ao reagirem às novas condições, passam a enfatizar suas qualidades pessoais. A televisão, sobretudo, intensifica a personalidade do candidato, fazendo com que a personalização da escolha política, característica do "parlamentarismo", seja retomada. Soma-se a isso o aumento das competências e atividades de governo, o que torna extremamente difícil fazer promessas políticas detalhadas. Os programas de governo ficam extensos e, para leigos (e até mesmo para os candidatos), incompreensíveis. Além disso, após a Segunda Guerra, houve um aumento da interdependência e um aprofundamento das relações internacionais entre Estados e agentes transnacionais, fazendo com que os problemas políticos se tornassem cada vez menos previsíveis diante de eventuais circunstâncias no decorrer de um mandato. Assim a demanda por um poder discricionário cada vez maior dos governantes acabou por inviabilizar debates em torno das plataformas e promessas eleitorais. Com isso, esse modelo acaba deixando um pouco de lado as discussões acerca de plataformas políticas. 
Também nesse modelo, devido ao realce da personalidade dos candidatos, os eleitores tendem a votar em uma pessoa, e não em um partido, fazendo com que os resultados eleitorais variem substancialmente de uma eleição para outra. Ainda que isso sugira uma aparente crise de representatividade constante, constatada pela inconstância dos eleitores, deve-se ter em mente que a preponderância da legenda partidária sobre a pessoa do candidato é uma característica específica só da democracia de partido. Logo, embora uma crise de representatividade (decorrente do afastamento entre eleitores e representantes) tenha sido um dos fatores para que a democracia do público emergisse, isso não significa que esse modelo esteja em crise constante. Mesmo porque os fatores pessoais dos candidatos e a relação de pessoalidade entre representantes e representados tomaram novas proporções, sobretudo nos países onde o chefe do poder executivo é eleito diretamente por sufrágio universal.

Algumas das consequências possíveis da nova personalização política nos processos eleitorais recentes são, como expõe Eatwell ${ }^{29}$, o populismo e o fascismo. A aparência de crise constante ocasionada por esse modelo, somada à personalização das escolhas eleitorais, faz com que figuras "messiânicas" que irão "purgar" o sistema político da crise possam surgir em contextos de distanciamento entre os eleitores e os representantes.

\section{Das crises de representatividade às crises do Direito}

Conforme já mencionado, o Direito - compreendido como o conjunto de instituições jurídicas e judiciárias (bem

29 EATWELL, 2017. 
como as formas de acesso a elas), o processo legislativo e os seus frutos (as leis) e as formas de interpretação das leis e da Constituição da República - é uma categoria profundamente atrelada à representação. Sendo assim, se as crises de representação - oriundas da dificuldade de conciliar a participação popular efetiva com o efeito aristocrático - são constantes do governo representativo, isso significa que as crises no Direito também o são. Entretanto, na medida em que o Direito é composto por aparatos e dispositivos estabilizadores e estáveis, os efeitos das crises tendem a se acoplar às práticas e instituições jurídicas, fenômeno que será examinado a partir da realidade do Brasil, mas que pode ser estendido ao Ocidente.

No que diz respeito às instituições judiciárias, por exemplo, tem-se que o judiciário brasileiro é composto, como apontam dados do Censo do Poder Judiciário ${ }^{30}$, 64\% dos magistrados são do sexo masculino, ao passo que, nos tribunais superiores, $82 \%$ dos juízes são homens, valendo destacar que $51,6 \%$ dos brasileiros são mulheres. Além disso, há vários tribunais de justiça e federais que jamais foram presididos por mulheres. No que diz respeito à composição étnico-racial dos juízes brasileiros (em todas as instâncias), 84,5\% se consideram brancos, ao passo que $14 \%$ se consideram pardos e apenas $1,4 \%$ pretos e $0,1 \%$, indígenas. Ainda, existem apenas 91 deficientes num universo de pouco mais de 17 mil juízes.

No texto "O Perfil do Aluno da EMERJ: Um estudo sobre "concursandos'", Fontainha realizou um estudo com 704 alunos que frequentaram, em junho de 2009, o "Curso de Especialização em Direito para a Carreira da Magistratura do Estado do Rio de Janeiro", visando traçar o perfil de quem visa ingressar na carreira da magistratura. No estudo, no campo "empresa onde trabalha", 504 dos 704 alunos, ou

CNJ, 2014, p.110-121. 
seja, 71,59\% deixaram o item em branco. Segundo o autor, "[...] o alto grau de não preenchimentos do campo 'empresa onde trabalha' apenas revela o fato de que a imensa maioria dos concursandos dedica-se exclusivamente a essa atividade, e, ainda, que advogados inscritos não possuam um local de trabalho" ${ }^{31}$. Além disso, 57,53\% dos alunos declaram residir na Zona Sul, na Barra da Tijuca ou em Niterói, o que revela certa relação com a possibilidade de possuir recursos financeiros para a preparação para concursos, preparação essa que gera despesas e impede ganho material.

Os referidos dados possuem forte relação com a já apontada tendência elitista do governo representativo. Se há uma propensão de os eleitores votarem apenas nas elites ou em indivíduos apoiados/financiados por elas, na medida em que elas possuem melhores meios de se tornarem notáveis, disso decorre que os desdobramentos de um governo eleito (leis, nomeações, atos administrativos) tenderão a ser pouco democráticos, muito embora sejam artificialmente representativos. Assim, ainda que paire a sensação de que as instituições (político-representativas e judiciárias) continuam a funcionar em períodos de crises, tal funcionamento pode criar situações de crise com aparência de normalidade, sendo a distorção presente nos dados apresentados um exemplo claro desta aparência.

Com efeito, as distorções acarretadas pelas crises de representação não ficam restritas a um déficit representativo numérico no poder judiciário, mas se projetam para as decisões do referido poder, ou seja, para a interpretação das leis, para a constituição e, sobretudo, para as práticas jurídicas, valendo apontar alguns exemplos extraordinários (que, muitas vezes, são tratados como ordinários). $\mathrm{O}$ primeiro e mais corriqueiro diz respeito à questão do dano

31 FONTAINHA, 2011, p.19. 
moral. O dano moral é compreendido como um agravo que não produz efeito material, ou seja, são danos à honra, integridade física e individual, reputação, etc. ${ }^{32}$, podendo gerar, ao causador do dano, o dever de indenizar. O que é interessante notar é que a capacidade econômica das partes envolvidas se impõe como parâmetro para fixação do valor da indenização, ou seja, aquele que possui mais ou menos pagará de acordo com seu patrimônio, assim como aquele que receberá a indenização. A distorção que, muitas vezes (na medida em que já há quem a tenha contestado), aqueles que são hipossuficientes tendem a receber um valor menor que os abastados, como se um abalo à honra destes fosse mais grave que à daqueles, segundo jurisprudência do próprio Superior Tribunal de Justiça.

Outro exemplo a ser pontuado é o caráter hostil com que, muitas vezes, o sistema de justiça trata movimentos que reivindicam direitos que são assegurados apenas a alguns (dentre os quais, aqueles que residem na Zona Sul do Rio de Janeiro). Leonidio ${ }^{33}$, em "A criminalização do MST e a formação dos operadores do sistema de justiça no Brasil", aponta, com um balança quantitativo de ações julgadas pelo Tribunal de Justiça do Estado de São Paulo, “claras intenções criminalizadoras das ações do MST".

[...] em relação aos mandados de reintegração/manutenção de posse, a sua quase totalidade é em caráter liminar. Além disso, contrariando o princípio constitucional segundo o qual o Juiz deve agir sob demanda, grande parte destes mandados são acompanhados pela ordem de resguardo de distância de $10 \mathrm{~km}$ dos sem terra em relação à propriedade, mesmo quando a parte não o solicita. Além disso, grande parte das ações decorreram de ocupações (ou não) de fazendas que se localizam em áreas já julgadas devolutas

32 CAHALI, 2000, p.20.

33 LEONIDIO, 2014, p.422 
ou que não cumprem a chamada função social da terra, conforme lista elaborada pela Comissão Pastoral da Terra (2007).

$\mathrm{O}$ que se pode inferir destes exemplos, a partir dos dados e análises sobre o governo representativo, é que a crise do Direito é patente. Ainda, não obstante uma crise nas instituições e na interpretação, emergem, em momentos nos ápices das crises de representatividade, leis não democráticas feitas pelos representantes. Pode-se falar em uma tripla crise: crise na confecção do direito; crise das práticas jurídicas; crise nos que interpretam o Direito (tudo isso ligado à crise de representação). E se uma aparência de crise como algo constante paira no âmbito do governo representativo - na medida em que "crises" deveriam ser momentos de exceção -, de modo que este estado se projeta para o âmbito do Direito, disso decorre que o Direito se torna um espaço de exceções. E, ainda que a tese institucionalista aponte para o funcionamento das instituições (pautados, em grande medida, na crença de que a realização de eleições, o processo legislativo levado a cabo pelos eleitos, as normas de acesso aos ofícios jurídicos feitas pelos representantes e as nomeações), exemplos "excepcionais" desta crise não faltam.

Matos e Gomes, em "O estado de exceção no Brasil republicano", apontam uma série de situações nas quais leis (elaboradas por representantes eleitos) e decisões judiciais (proferidas por juízes escolhidos pelos representantes) evidenciam os desdobramentos jurídicos da crise do governo representativo, dentre os quais a "lei da copa". Vale também, para além da referida lei, fazer menção ao julgamento, pelo Supremo Tribunal Federal, da lei de anistia.

A referida lei da Capa, além de restringir a liberdade de expressão, na medida em que estabelece à FIFA a titularidade exclusiva dos direitos de imagem e mídias no que diz respeito à Copa, permitia a venda casa por esta institui- 
ção - prática expressamente vedada pelo Código de Defesa do Consumir. Além disso, impunha sérias restrições à livre iniciativa, já que proibia a comercialização de bens e serviços nos denominados "territórios FIFA". Como expõe Matos, em "A Copa da exceção no tribunal da Teoria Pura do Direito":

No art. 12, a Lei Geral da Copa (LGC) estabelece várias restrições à liberdade de expressão, definindo a FIFA como titular exclusiva dos direitos relativos às imagens, aos sons e a outras formas de divulgação da Copa, incluindo aí o direito de explorar, negociar, autorizar e proibir suas transmissões ou retransmissões. Já no seu art. 27, a LGP admite a possibilidade da chamada venda casada, prática vedada pelo art. 39 do Código de Defesa do Consumidor, o qual está suspenso no que se relaciona à Copa. A demonstrar para que lado pende a balança da soberania, o art. 22 da LGC prevê que, caso o Brasil não consiga fazer cumprir todas as exigências da FIFA, a União Federal responderá pelos danos que causar, por ação ou omissão, a seus representantes legais, empregados ou consultores. Outro exemplo significativo de exceção é a suspensão do polêmico dispositivo do Estatuto do Torcedor que proíbe a venda e o consumo de bebidas alcoólicas em estádios brasileiros ${ }^{34}$.

Vale ressaltar que a maximização da atuação penal do Estado, o monopólio de exploração econômica por parte da FIFA, a criação de exceções de um modo geral, foram chancelados pelas instâncias judiciárias, sobretudo nas proibições referentes a manifestações de "cunho político" nos estádios.

É ainda mais representativo da crise o julgamento, por parte do STF, da constitucionalidade da Lei de Anistia, bem como uma série de outras problemáticas que circunscrevem esta questão. A lei 6.683, de 28 de agosto de 1979, concedeu anistia a todos aqueles que cometeram crimes políticos ou a estes conexos entre 2 de setembro de 1961 e 15 de agosto de 1979. Esse mesmo diploma legal estabelece que os benefícios da anistia não serão estendidos aos que praticaram os

34 MATOS, 2014, p.64. 
crimes de sequestro, atentado pessoal, terrorismo e assalto. Noutros termos, "[...] sequestros e atentados pessoais de toda ordem cometidos por membros do regime militar nunca foram objeto de anistia (sequer na lei que os próprios militares se autoconcederam). Isso sem falar que uma lei que fala em crimes de terrorismo não pode se furtar a condenar crimes de terrorismo de Estado" ${ }^{\prime 35}$.

No entanto, um dos arautos da ala conservadora do STF, presidente atual do referido tribunal, chegou ao limite de evocar o artigo 5, inciso 44, da Constituição nacional a m de justificar que, caso militares fossem julgados por tortura, assassinato, sequestro, atentado pessoal e ocultação de cadáveres, então antigos membros da luta armada deveriam ter o mesmo destino. Em um destes lapsos reveladores e patéticos em que o enunciador não percebe o que realmente diz, o referido ministro fundava sua argumentação no seguinte texto da lei constitucional: "Constitui crime inafiançável e imprescritível a ação de grupos armados, civis ou militares, contra a ordem constitucional e o Estado democrático". Como se vê, o texto constitucional é de uma clareza cristalina. Sua ideia é: o Estado democrático, este no qual os princípios democráticos fundamentais estariam assegurados e implementados, compreende como crime imprescritível a tentativa de grupos armados (ou das próprias Forças Armadas, como sempre foi o caso no Brasil) em destruí-lo. Que um ministro do STF compreenda que isto implica também a condenação constitucional de ações armadas contra o Estado militar que vigorou no Brasil entre 1964 e 1984 só pode significar que, para ele, não há diferença estrutural entre Estado democrático e Estado ditatorial, ou que simplesmente não havia ditadura no Brasil naquele período. Ou seja, a lei é muito clara na sua função de defender o Estado Democrático, esse mesmo Estado cujos rudimentos foram destruídos pelo golpe militar de $1964^{36}$.

No referido julgamento - Arguição de Descumprimento de Preceito Fundamental número 153 -, foi alegada a controvérsia constitucional acerca da Lei de Anistia, buscan-

35 SAFATLE, 2010, p.242.

36 SAFATLE, 2010, p.243. 
do saber que este diploma anistiou os agentes públicos que perpetraram crimes de homicídio, tortura, desaparecimento forçado, lesões corporais, estupro, etc., contra os opositores do governo militar. Vale dizer que a referida lei foi editada por um Congresso Nacional “eleito" em um momento de, no mínimo, manifesta exceção. Isso porque, conforme expõe $\mathrm{Kinzo}^{37}$, as eleições desse período eram marcadas por uma série de instrumentos manipulatórios - dentre os quais os "senadores biônicos" -, a fim de assegurar aos militares a maioria parlamentar e, ainda assim, sustentar, perante a comunidade internacional, que as "estruturas representativas" continuavam a funcionar. Não obstante, Carvalho ${ }^{38}$ demonstra como o regime militar beneficiou aos mais abastados. Em 1960 os 20\% mais pobres da população ativa economicamente ganhava 3,9\% da renda nacional. Em 1980, esse mesmo grupo recebia 2,8\%. Por outro lado, se em 1960 os $10 \%$ mais ricos ganhavam $39,6 \%$ da renda nacional, em 1980 sua participação subira para 50,9\%. Ainda, a parcela representada no $1 \%$ mais rico ganhava 11,9\% em 1960 e em 1980 passou a ganhar $16,9 \%$. Noutros termos, embora tenham ocorrido períodos de crescimento econômico de acordo com os índices oficiais (o "milagre econômico), os ganhos econômicos apenas acirraram as desigualdades sociais.

Assim, vale notar que se nesse período havia este claro favorecimento, por parte dos representantes, de uma parcela diminuta da sociedade (favorecimento este chancelado pelas instituições judiciárias da época), tal favorecimento, levado a cabo às custas dos torturados, foi chancelado pelas estruturas judiciárias de um momento "democrático". Pode-se dizer que o STF, ao reconhecer a constitucionalidade de uma lei elaborada em um momento de sérias restrições a direitos

37 KINZO, 1988.

38 CARVALHO, 2001, p.168-169. 
políticos, crescente desigualdade social, manipulação de imprensa, etc., chancela as distorções jurídicas de um período de exceção. Mais ainda, demonstra que a aparência de continuidade institucional das estruturas representativas, que elaboram as leis, nomeiam os juízes de cúpula e estabelecem os critérios legais de acesso às carreiras jurídicas, dificultem a percepção de que a crise do Direito está atrelada à crise democrática moderna.

\section{Considerações finais}

Como examinado, cabe ao corpo de representantes estabelecer, pelo processo legislativo, os instrumentos jurídicos que os juízes devem interpretar e aplicar em suas decisões. Igualmente, cabe aos eleitos conceber as normas por meio das quais os cidadãos podem ingressar nos ofícios jurídicos. Além disso, os representantes cuidam da nomeação dos juízes dos tribunais superiores e da instância máxima, essas responsáveis pela uniformização jurisprudencial no que diz respeito à legislação federal e à constituição, respectivamente.

Pois bem, considerando que paira uma certa indistinção entre eleição e democracia, como se ambas fossem sinônimas, o intento deste artigo foi demonstrar que os processos eleitorais nem sempre levam à democratização dos processos decisórios. E, mais ainda, tendo em vista que no âmbito desses processos decisórios representativos estão as instituições jurídicas, as leis, as constituições, as nomeações de juízes, as normas relativas à escolha dos juízes, etc., bem como uma certa tendência aristocrática no governo representativo, muitas das distorções e manifestações de crises no direito atual parecem decorrer desta indistinção. Quando, por exemplo, magistrados entendem que estão chancelados 
pela soberania popular, já que se tornaram juízes seguindo os ritos estabelecidos por indivíduos eleitos, o mais acertado seria dizer que eles são "representativos", embora não sejam representantes. Noutros termos, soberania popular e democracia não podem ser confundidas com representação. Com isso, se juízes negam acesso a direitos, fundamentando-se em suas prerrogativas e em determinadas leis, a crise que existe no âmago do governo representativo faz com que uma aporia surja.

Assim, falar em uma crise do Direito no século XXI parece ser uma incoerência, na medida em que o Direito moderno se constitui em uma aporia que, em alguns momentos, se manifesta em crises de representação. Essas, embora pareçam pontuais, são fruto de uma tentativa de conciliar elementos aparentemente irreconciliáveis. Entretanto, uma série de artificialidades fazem com que alguns atenuantes mantenham a sustentabilidade de um modelo jurídico e político representativo (e não democrático).

\section{Referências}

BONAVIDES, Paulo. Ciência Política. 10ed. São Paulo: Malheiros Editores, 1997.

BRASIL. CONSELHO NACIONAL DE JUSTIÇA (CNJ). Censo do Poder Judiciário: VIDE: Vetores iniciais e dados estatísticos / Conselho Nacional de Justiça. Brasília: CNJ, 2014.

CAHALI, Yussef Said. Dano moral. 2 ed. São Paulo: Revista dos Tribunais, 2000.

CARVALHO, José M.. Cidadania no Brasil. São Paulo: Civilização Brasileira, 2001.

CATTONI, Marcelo. “Direito, política e legitimidade: republicanismo, liberalismo e teoria do discurso". In: 
Direito, politica e filosofia. Rio de Janeiro: Lumen Juris, 2007. COSTA, H. O.. "Crise dos partidos e as transformações dos governos representativos". Revista Cronos, v.11, n.1,274, 2010 .

DAHL, Robert A. A democracia e seus críticos. Trad. P. F. Ribeiro. São Paulo: Editora WMF Martins Fontes, 2012.

EATWELL, R.. "Populism and Fascism". In: TAGGART, P. e KALTWASSER, C. R. (orgs.). The Oxford Handbook on Populism. Oxford: Oxford University Press, 2017.

FONTAINHA, Fernando. "O Perfil do Aluno da EMERJ: Um estudo sobre 'concursandos'”. R. EMERJ, v.14, n.56, p.7-31, 2011.

FOUCAULT, Michel. Em Defesa da Sociedade. Trad. M. E. Galvão. São Paulo: Martins Fontes, 1999.

KINZO, M. D'Alva. Oposição e Autoritarismo: gênese e trajetória do PMDB (1966-1979). São Paulo: Editora IDESP, 1988.

KIRCHHEIMER, Otto. “A transformação dos sistemas partidários da Europa Ocidental". Revista Brasileiro de Ciência Política, n.7, 2012.

LEONIDIO, Adalmir. "A criminalização do MST e a formação dos operadores do sistema de justiça no Brasil". Antíteses, v.7, n.14, p. 417-441, 2014.

MANIN, Bernard. The principles of representative government. Cambridge: Cambridge University Press, 1997.

MCCORMICK, John. Machiavellian democracy. Nova Iorque: Cambridge University Press, 2011.

MARRAMAO, Giacomo. "Para captar a lógica do nosso presente, devemos recorrer aos grandes teóricos da conjuntura". Entrevista com Giacomo Marramao. Instituto 
Humanitas Unisinos. Disponível em: http://www.ihu. unisinos.br/78-noticias/573166-para-captar-a-logica-de-nosso-presente-devemos-recorrer-aos-grandes-teoricos-da-conjuntura-entrevista-com-giacomo-marramao. Acesso no dia 2 de janeiro de 2017. Porto Alegre, 31 de outubro de 2017. MATOS, Andityas. "A Copa da exceção no tribunal da Teoria Pura do Direito". Revista Direito e Práxis, Rio de Janeiro, v.5, n.8, p.49-75, 2014

MATOS, Andityas e GOMES, Ana. “O estado de exceção no Brasil republicano". Revista Direito e Práxis, Rio de Janeiro, v.8, n.3, p.1760-1787, 2017.

SAFATLE, Vladimir. "Do uso da violência contra o Estado ilegal”. In. SAFATLE, Vladimir Pinheiro e TELES, Edson (orgs.). O que resta da ditadura. São Paulo: Editora Boitempo, 2010.

SCHUMPETER, Joseph A.. Capitalismo, socialismo e democracia. Trad. R. Jungmann. Rio de Janeiro: Editora Fundo de Cultura, 1961.

URBINATI, Nadia. “O que torna a representação democrática?". Revista Lua Nova, v.67, p.191-228, 2006.

WEBER, Max. "A Política como Vocação". In:

Ensaios de Sociologia. Org. e int. H. H. Gerth e C. Wright Mills. Trad. W. Dutra. Rio de Janeiro: LTC Editora, 1982. 
Recebido em 27/03/2018

Aprovado em 06/03/2020

Adriana Campos Silva

E-mail: adrilaw@hotmail.com

Ricardo Manoel de Oliveira Moraes

E-mail: ricardo_mom@hotmail.com 
